\title{
Effect of professional dental prophylaxis with sodium bicarbonate jet on the cariogenic microbiota ${ }^{\dagger}$ Efeito da profilaxia profissional com jato de
bicarbonato de sódio sobre a microbiota cariogênica
}

Célia Regina Moreira LANZA*

José Eduardo de Oliveira LIMA**

Sergio Aparecido TORRES***

Maria Aparecida de Andrade Moreira MACHADO**

\begin{abstract}
LANZA, C. R. M; LIMA, J. E. de O.; TORRES, S. A.; MACHADO, M. A. de A. M. Effect of professional dental prophylaxis with sodium bicarbonate jet on the cariogenic microbiota. Pesq Odont Bras, v. 14, n. 1, p. 87-92, jan./mar. 2000.

The effect of professional dental prophylaxis with sodium bicarbonate jet on salivary counting of mutans streptococci and lactobacilli in 32 children ranging from 7 to 10 years of age, has been assessed. Whole stimulated saliva was collected before the prophylaxis, immediately after it and 30 days later, and the number of $\mathrm{CFU} / \mathrm{ml}$ in the saliva was detected through the Caritest system. A statistically significant immediate decrease on salivary levels of both microorganisms was observed, $50 \%$ for mutans streptococci and $27 \%$ for lactobacilli. For mutans streptococci this decrease continued through the 30 days period; the same did not occur with lactobacilli, that returned to their baseline values.
\end{abstract}

Uniterms: Dental prophylaxis; Sodium bicarbonate; Streptococcus mutans; Lactobacillus.

\section{INTRODUCTION}

Dental caries is a multifactorial disease in which some dental plaque microorganisms, especially mutans streptococci and lactobacilli, play the main role. Positive correlations have been shown between the countings of these microorganisms and caries prevalence and activity ${ }^{1,7,11}$, and a great deal of emphasis has been put on chemical or mechanical control of bacterial plaque. Good oral hygiene, associated to periodic professional care, has been considered the most effective method for bacterial plaque control. In Pediatric Dentistry, considering the child's difficulties to perform auto-mechanical removal of bacterial plaque, as a function of immaturity and lack of motor coordination, and because these procedures are easily unmotivating, professional dental cleaning, regularly, has a special significance ${ }^{3,5,9,12}$.

Air polishing devices that use sodium bicarbonate jet under compression, since they were introduced in the marketplace in the late seventies, have been considered an efficient and quick choice for bacterial plaque removal on the various dental surfaces $^{2,13,16}$. In Pediatric Dentistry they present some advantages over conventional polishing techniques; they are the method of choice for cleaning teeth with orthodontic brackets or bands ${ }^{13}$ and enable a deeper cleaning of fissures before sealant application $^{6}$, without causing any damage to deciduous $^{8}$ or permanent teeth enamel ${ }^{15,16}$.

The discovery of a direct correlation between certain bacterial numbers in dental plaque and in saliva $^{11,14,17,20}$ favors the use of stimulated whole saliva to assess the efficacy of some oral hygiene and dental caries prevention measures. Thus, this work aimed to ascertain the immediate effect of dental prophylaxis with a sodium bicarbonate jet on the cariogenic microbiota of the oral cavity and its recolonization, 30 days later.

\section{MATERIAL AND METHODS}

Thirty-two 7-10-year-old children took part in the experiment, 19 females and 13 males, in a mixed dentition status, without clinically visible caries lesions nor evident systemic infections. They did not bear orthodontic appliances and they

$\dagger$ Part of the Master Degree Essay.

*Graduate Student, Department of Pediatric Dentistry; ** Doctorate Degree, Department of Pediatric Dentistry; *** Doctorate Degree, Department of Oral Pathology - School of Dentistry, University of São Paulo - Bauru. 
LANZA, C. R. M; LIMA, J. E. de O.; TORRES, S. A.; MACHADO, M. A. de A. M. Effect of professional dental prophylaxis with sodium bicarbonate jet on the cariogenic microbiota. Pesq Odont Bras, v. 14, n. 1, p. 87-92, jan./mar. 2000.

had not used antibiotics for the previous 30 days. These children did not have a clinical history of sodium restriction in their diet, nor severe respiratory or renal diseases. Parents or responsible persons were informed about the research content and signed an informed consent authorizing the child's participation in the study. No instructions about diet or dental brushing were given, so as not to change these patient habits during the experimental period.

A professional dental prophylaxis with sodium bicarbonate jet under compression was provided for each patient, using Profident (Dabi-Atlante, Ribeirão Preto-SP), after disclosing the bacterial plaque with $0.5 \%$ basic fucsin. Profident was used by a single operator, following the manufacturer's instructions, with the spray reaching the dental surface at an oblique angle ranging from $45^{\circ}$ to $85^{\circ}$, towards gingival sulcus, at a mean maximum distance of 4 to $5 \mathrm{~mm}$.

\section{Microbiologic procedures}

Three samples of stimulated whole saliva were collected from each patient, before prophylaxis, 60 minutes after it and 30 days later. Caritest-SM and Caritest-LB Systems (Herpo Produtos Dentários Limitada, Rio de Janeiro) were used to detect mutans streptococci and lactobacilli, respectively. The children were asked to chew a chewing gum tablet until it was completely soft. Thus, about $5.0 \mathrm{ml}$ of stimulated saliva were collected into $15 \mathrm{ml}$ sterile tubes, and maintained on ice until they were taken to the Microbiology laboratory. The salivary samples were stirred for $1 \mathrm{~min}-$ ute under maximum speed (MIXTRON, Leucotron Equipment Ltd) to help the dispersion and homogenization of the microorganisms. All stimulated whole saliva samples were collected in the morning, after a 1-2 hour interval from the last food ingestion, according to the time interval patterning for sampling with children, as proposed by TOGELIUS et $a l^{2}(1984)$.

For the microbiologic test with Caritest- SM, bacitracin was added to the tube with a diluting medium, and $1.5 \mathrm{ml}$ of homogenized saliva was aseptically transferred, following the manufacturer's directions. Slides with the culture medium of Caritest-SM were seeded through immersion into this diluent-saliva mixture, and immediately replaced into their original tube. Two drops of water were added to the $\mathrm{CO}_{2}$ generating powder and the tubes were closed. For Caritest-LB, $1.5 \mathrm{ml}$ of saliva was transferred to the diluent containing tube, and the slide with the culture medium was seeded through its immersion into this mixture. These tubes were incubated at $37^{\circ} \mathrm{C}$ for 48 hours, kept for another 24 hours at room temperature, when the colony growth density on the culture medium was compared to the values printed on a result assessment board, presented on the Caritest package. This board enabled the identification of 6 different levels of bacterial infection: 10,000 $\mathrm{CFU} / \mathrm{ml} ; \quad 50,000 \mathrm{CFU} / \mathrm{ml} ; \quad 100,000 \mathrm{CFU} / \mathrm{ml}$; $250,000 \mathrm{CFU} / \mathrm{ml} ; 500,000 \mathrm{CFU} / \mathrm{ml}$ and $1,000,000$ $\mathrm{CFU} / \mathrm{ml}$. The considered rates of cariogenic activity were: very low risk (< 10,000 CFU/ml); low risk (< 100,000 CFU $/ \mathrm{ml})$; high risk $(>100,000$ $\mathrm{CFU} / \mathrm{ml}$ ); very high risk ( $>1,000,000 \mathrm{CFU} / \mathrm{ml}$ ) for mutans streptococci and low risk $1<10,000$ $\mathrm{CFU} / \mathrm{ml}$ ); high risk (> 10,000 $\mathrm{CFU} / \mathrm{ml})$ and very high risk $(>100,000 \mathrm{CFU} / \mathrm{ml})$ for lactobacilli.

Differences in mutans streptococci levels between the three examinations were evaluated by the Student $t$ test. Data analysis was performed with the help of Microstat computer software .

\section{RESULTS AND DISCUSSION}

Thirty-one children concluded the study, only one was eliminated because of antibiotics use during the period between the second and the third saliva sampling. Mutans streptococci were detected in $100 \%$ of the individuals and lactobacilli in $87.09 \%$ (Table 1). Mean quantitative values are shown on Table 2, and the differences attained after prophylaxis are shown on Table 3 . The prevalence of mutans streptococci detected through this study was higher than that found by WEINBERGER; WRIGHT ${ }^{22}$ (1990) with 16-60month-year-old children and by ALALUUSUA; MYLLÄRNIEMI; KALLIO ${ }^{1}$ (1989) with 5-year-old children and coincides to the data obtained by KÖHLER; PETTERSSON; BRATTHALL ${ }^{11}$ with 13-16-year-old adolescents.

Data from the first to the second assessments showed that professional dental prophylaxis, performed with Profident, significantly decreased the salivary levels of mutans streptococci (Tables 2 and 3 ) by about $50 \%(t=1.753 ; P=0.049)$. A decrease was observed in $23(74.2 \%)$ children; in one of them $(3.2 \%)$ there was an increase on the number of these microorganisms, and in 7 children $(22.6 \%)$ the levels did not change (Table 1). It is important to emphasize that these 7 children had low initial levels of salivary mutans streptococci $\left(<10^{5} \mathrm{CFU} / \mathrm{ml}\right)$. Also, there was a statistically sig- 
LANZA, C. R. M; LIMA, J. E. de O.; TORRES, S. A.; MACHADO, M. A. de A. M. Effect of professional dental prophylaxis with sodium bicarbonate jet on the cariogenic microbiota. Pesq Odont Bras, v. 14, n. 1, p. 87-92, jan./mar. 2000.

TABLE 1 - CFU/ml salivary counting of mutans streptococci (SM) and lactobacilli (LB).

\begin{tabular}{|c|c|c|c|c|c|c|}
\hline \multirow{3}{*}{ Patient } & \multicolumn{6}{|c|}{ Saliva sample ( CFU/ml x 10 $)$} \\
\hline & \multicolumn{2}{|c|}{ Baseline } & \multicolumn{2}{|c|}{$\begin{array}{c}\text { After } \\
\text { prophylaxis }\end{array}$} & \multicolumn{2}{|c|}{30 days later } \\
\hline & $\mathrm{SM}$ & LB & SM & LB & SM & LB \\
\hline 1 & 250 & 10 & 0 & 10 & 250 & 10 \\
\hline 2 & 10 & 0 & 10 & 0 & 10 & 0 \\
\hline 3 & 500 & 10 & 50 & 10 & 100 & 500 \\
\hline 4 & 10 & 50 & 50 & 10 & 50 & 100 \\
\hline 5 & 50 & 250 & 50 & 250 & 10 & 50 \\
\hline 6 & 50 & 1000 & 50 & 500 & 50 & 1000 \\
\hline 7 & 250 & 1000 & 50 & 250 & 50 & 250 \\
\hline 8 & 50 & 10 & 50 & 10 & 10 & 10 \\
\hline 9 & 50 & 0 & 10 & 0 & 50 & 10 \\
\hline 10 & 250 & 10 & 50 & 10 & 50 & 10 \\
\hline 11 & 10 & 10 & 10 & 10 & 50 & 10 \\
\hline 12 & 100 & 10 & 0 & 50 & 500 & 100 \\
\hline 13 & 250 & 50 & 10 & 50 & 250 & 250 \\
\hline 14 & 100 & 250 & 10 & 10 & 50 & 100 \\
\hline 15 & 1000 & 100 & 10 & 50 & 50 & 100 \\
\hline 16 & 50 & 10 & 10 & 10 & 10 & 10 \\
\hline 17 & 500 & 50 & 50 & 10 & 100 & 50 \\
\hline 18 & 10 & 0 & 0 & 0 & 10 & 10 \\
\hline 19 & 50 & 0 & 10 & 0 & 10 & 10 \\
\hline 20 & 250 & 500 & 250 & 100 & 50 & 500 \\
\hline 21 & 50 & 50 & 50 & 100 & 10 & 10 \\
\hline 22 & 500 & 50 & 250 & 50 & 100 & 50 \\
\hline 23 & 100 & 50 & 10 & 10 & 0 & 10 \\
\hline 24 & 500 & 500 & 50 & 500 & 50 & 1000 \\
\hline 25 & 250 & 100 & 10 & 100 & 50 & 50 \\
\hline 26 & 500 & 50 & 10 & 10 & 50 & 50 \\
\hline 27 & 250 & 500 & 50 & 250 & 250 & 500 \\
\hline 28 & 1000 & 100 & 100 & 100 & 250 & 1000 \\
\hline 29 & 250 & 500 & 100 & 250 & 250 & 250 \\
\hline 30 & 10 & 10 & 0 & 10 & 10 & 0 \\
\hline 31 & 100 & 100 & 50 & 100 & 50 & 250 \\
\hline
\end{tabular}

TABLE 2 - Mean parameters of $\mathrm{CFU} / \mathrm{ml}$ of saliva.

\begin{tabular}{|c|c|c|c|}
\hline \multirow{2}{*}{ Sampling } & & \multicolumn{2}{|c|}{ Mean $\left(x 10^{3}\right)$} \\
\hline & $\mathrm{N}$ & $\mathrm{SM}$ & LB \\
\hline Baseline & 31 & $235.48(263,87)$ & $171.93(274,88)$ \\
\hline After prophylaxis & 31 & $45.48 \quad(61,09)$ & $89.67(136,56)$ \\
\hline 30 days later & 31 & $89.67 \quad(112,02)$ & $201.61(305,14)$ \\
\hline
\end{tabular}

$\mathrm{SM}$ - mutans streptococci.

LB - lactobacilli.

nificant decrease in the lactobacilli levels (Table 2 and 3$)$, around $27 \%(t=1.719 ; \mathrm{P}=0.047)$. Among the assessed children, 11 (35.5\%) showed lower levels than the initial ones, 18 (58.1\%), similar levels and, 2 (6.45\%), higher levels (Table 1).

A transient decrease of about $64 \%$ in the salivary concentration of mutans streptococci has been found by WIKNER ${ }^{23}$ after visible plaque complete removal, but this procedure did not change lactobacilli concentration. CAUFIELD; GIBBONS ${ }^{4}$ did not find a decreasing effect in the number of mutans streptococci in saliva after prophylaxis only, but when it was complemented by topical application of iodine solution there was a marked and lasting decrease in the rates of the referred microorganisms. EMILSON; AXELSSON; KALLEN$\mathrm{BERG}^{5}$ found a caries activity decrease after one year, without the decrease of the salivary levels of these microorganisms and ascribed the cariostatic effect to other factors, considering the possibility that the fortnightly performed cleaning procedures led to remineralization of initial carious lesions. According to KLOCK; KRASSE ${ }^{9}$, similar results are due to symptomatic treatment of infection and to increase in enamel resistance. HÖFLING et al. ${ }^{7}$ report that the data obtained on countings of these microorganisms should not be considered in absolute terms, but should be associated to other salivary factors and to cariogenic activity.

An immediate cariogenic microbiota decrease, verified after prophylaxis with sodium bicarbonate jet, may be due to the fact that this technique is an effective cleaning method for the removal of the plaque present on more retentive dental sites, such as occlusal ${ }^{6}$ and proximal surfaces and restoration interfaces ${ }^{13,16}$. LINDQUIST; EMILSON; WENNERHOLM ${ }^{14}$ found that the 10 surfaces that were better correlated to the mutans group streptococci salivary pool were 5 upper posterior 
LANZA, C. R. M; LIMA, J. E. de O.; TORRES, S. A.; MACHADO, M. A. de A. M. Effect of professional dental prophylaxis with sodium bicarbonate jet on the cariogenic microbiota. Pesq Odont Bras, v. 14, n. 1, p. 87-92, jan./mar. 2000.

TABLE 3 - Differences between the mean $\mathrm{CFU} / \mathrm{ml}$ of saliva. Paired observations.

\begin{tabular}{c|c|l|l}
\hline \hline & $\begin{array}{c}\text { Baseline and } \\
\text { after prophylaxis }\end{array}$ & $\begin{array}{l}\text { After prophylaxis } \\
\text { and 30 days later }\end{array}$ & $\begin{array}{c}\text { Baseline and } \\
\text { 30 days later }\end{array}$ \\
\hline SM & $\mathrm{t}=4.1637(\mathrm{sg})$ & $\mathrm{t}=-1.9519(\mathrm{sg})$ & $\mathrm{t}=-3.1153(\mathrm{sg})$ \\
\hline LB & $\mathrm{t}=2.5603(\mathrm{sg})$ & $\mathrm{t}=-2.751(\mathrm{sg})$ & $\mathrm{t}=-0.6337$ \\
\hline \hline
\end{tabular}

(sg) - statistically significant difference $\mathrm{p}<0.01$.

$\mathrm{t}$ - critical value of Student $t$ test.

$\mathrm{SM}$ - mutans streptococci.

LB - lactobacilli.

interproximal and 5 vestibular sites. According to ALALUUSUA; MYLLÄRNIEMI; KALLIO ${ }^{1}$, the approximal sites, and to SCHAEKEN; CREUGERS; VAN DER HOEVEN ${ }^{17}$, fissures and interproximal areas are reservoirs for mutans streptococci because they are less affected by oral hygiene measures. Additional factors that might have an influence over salivary assessments must also be considered; and they may be related both to saliva sampling and to microbiologic processing, such as, for example, culture medium selection, bacitracin content, chewing intensity, as well as to direct factors arising from oral hygiene procedures, or from the diet.

In the third salivary sample, obtained 30 days later (Table 2), we noticed that the decrease in $\mathrm{CFU} / \mathrm{ml}$ number of mutans streptococci persisted in about $27 \%$ of the subjects $(t=1.726 ; \mathrm{P}=0.047)$. However, these values are different from those obtained immediately after prophylaxis, revealing the slow reestablishment of the microorganisms on the dental surfaces. For lactobacilli, salivary levels obtained after the 30 day period were similar to those obtained in the initial sampling, and no statistical difference was shown between them (Table 2 and 3). These data suggested that the period had been long enough for bacterial recolonization, that occurred, in this case, more rapidly than for mutans streptococci. A possible explanation for this fact may be related to sugar ingestion that, although not assessed by this study, may have favored lactobacilli; and also to the fact that prophylaxis had acted with less intensity over these microorganisms. There was a microbial decrease in only $8(25.8 \%)$ children; in $13(41.9 \%)$ there was no change, and in $10(32.2 \%)$ there was an increase (Table 1).

Profident (Dabi-Atlante), the device used for this experiment showed to be of easy handling, requiring only a little training by the operator and a previous disclosing of dental plaque to make its vi- sualization and removal easier. Generally, there was a good acceptance of the technique by the children that took part in the study, although some gingival bleeding occurred, which stopped immediately after the procedure was completed and after a thorough mouth rinse. Some children complained of a "salty taste".

Salivary counting was performed because it represents a rational measurement of the oral cavity microbiota, and of the number of colonized dental surfaces ${ }^{11,14,17,20}$, besides being less time consuming, easier and faster compared to dental plaque sampling. The choice of the Caritest system is partly due to its greater feasibility in a dental office, compared to the conventional methodology of dilution and plaque culture over Petri dishes, and also because it is the only one available in the Brazilian marketplace. Although bacteriological tests were within validity terms, contamination of some slides and of some diluting solutions was observed, as well as some variations in bacitracin envelopes and in $\mathrm{CO}_{2}$ generator, resulting in some test losses. The reading of the results was possible by visualization of the medium surface, although hindered by the subjectivity of the method, to analyse the growth density activity, as suggested by manufacturers.

The advantages of the use of simplified tests are their easy handling and the fact that they do not require the use of specific laboratory techniques that are more time and cost demanding, but their results are less accurate than those of the conventional method. KOGA et al. ${ }^{10}$ found a $75 \%$ correlation between Caritest-SM and the conventional method, considering it satisfactory, but a smaller correlation, of about 50\%, was observed for Caritest-LB. As a consequence of these observations, in this study special procedures during experiments were performed in order to achieve a higher result confidence, through bacteriological assays performed at the laboratory. The saliva sampling was carried out in sterile tubes and not directly on the test bottles as it had been proposed for use in dental offices. In addition, the result interpretation was performed by a microbiologist.

Mutans streptococci suppression was found after an intensive treatment during short periods with chemotherapeutic solutions and after mechanical control measures associated to chemical solutions or not. The success of these treatments is, however, only transient and within a few weeks, the microorganisms return to their original numbers in the saliva and on the teeth. The process through which this happens is very controversial 
LANZA, C. R. M; LIMA, J. E. de O.; TORRES, S. A.; MACHADO, M. A. de A. M. Effect of professional dental prophylaxis with sodium bicarbonate jet on the cariogenic microbiota. Pesq Odont Bras, v. 14, n. 1, p. 87-92, jan./mar. 2000.

but it is still intriguing researchers. Mutans streptococci recolonize dental surfaces when some reservoirs, such as fissures, enamel cracks, incipient lesions and junctions along restoration margins remain after treatment ${ }^{18}$. Another possibility is that soft tissues, specially the tongue, that were not reached by the mechanical treatment, restricted to mouth hard tissues, serve as microbial reservoirs for tooth recolonization. A third and important aspect to be considered is the fact that the mouth may become infected by new mutans streptococci. The reestablishment of these microorganisms may be related to a strong suppression of other bacteria, considering that the performed procedure is an unspecific measure and reaches all plaque microbiota. From clinical studies ${ }^{19}$ and from animal experiments ${ }^{21}$ it is known that oral bacteria, such as Actinomyces viscosus and Streptococcus sanguis, may delay or inhibit the establishment of mutans streptococci, through antagonism.

Although a significant decrease has been observed on the salivary levels of these microorganisms, only 4 children did not show these bacteria immediately after dental prophylaxis. Possibly, some microbial reservoirs remained in the oral cavity, enabling recolonization, but the data of this study do not allow definite considerations about this.

\section{CONCLUSIONS}

Bacteriological assessment of salivary samples allowed us to conclude that:

1. Dental prophylaxis performed with a sodium bicarbonate jet has been effective in the promotion of an immediate suppression on $\mathrm{CFU} / \mathrm{ml}$ counting of mutans streptococci and of lactobacilli, which was statistically significant.

2. This decrease persisted through a 30 day period for mutans streptococci; the same did not happen for lactobacilli, that after this period returned to their baseline values.

3. The use of a sodium bicarbonate jet requires other comparative assessments so as to establish its effect for longer time periods on dental caries prevention, associated to other preventive measures or not.

LANZA, C. R. M; LIMA, J. E. de O.; TORRES, S. A.; MACHADO, M. A. de A. M. Efeito da profilaxia profissional com jato
de bicarbonato de sódio sobre a microbiota cariogênica. Pesq Odont Bras, v. 14, n. 1, p. 87-92, jan./mar. 2000.

Avaliou-se o efeito da profilaxia dentária profissional com o jato de bicarbonato de sódio na contagem salivar de estreptococos do grupo mutans e de lactobacilos em 32 crianças entre 7-10 anos. Coletou-se saliva total estimulada antes e 60 minutos após o procedimento, e decorridos 30 dias, sendo o número de UFC $/ \mathrm{mL}$ saliva detectado através do sistema Caritest. Constatou-se uma redução imediata, estatisticamente significativa, nos niveis salivares de ambos os microrganismos, sendo de $50 \%$ para estreptococos do grupo mutans e de $27 \%$ para lactobacilos. Para os estreptococos do grupo mutans, esta redução persistiu pelo período de 30 dias, o mesmo não ocorrendo para os lactobacilos, que retornaram aos seus valores iniciais.

UNITERMOS: Profilaxia dentária; Bicarbonato de sódio; Streptococcus mutans; Lactobacillus.

\section{BIBLIOGRAPHIC REFERENCES}

1. ALALUUSUA, S.; MYLLÄRNIEMI, S.; KALLIO, M. Streptococcus mutans infection level and caries in a group of 5-year-old children. Caries Res, v. 23, n. 3, p. 190-194, 1989.

2. AMERICAN DENTAL ASSOCIATION. Council on Dental Materials, Instruments, and Equipment. Status report on professional scaling and stain-removal devices. J Am Dent Assoc, v. 111, n. 5, p. 801-802, Nov. 1985.

3. AXELSSON, P.; LINDHE, J. The effect of a preventive programme on dental plaque, gingivitis and caries in schoolchildren. Results after one and two years. $\mathbf{J}$ Clin Periodonto, v. 1, n. 2, p. 126-138, 1974.

4. CAUFIELD, P. W.; GIBBONS, R. J. Supression of Streptococcus mutans in the mouth of human by a dental pro- phylaxis and topically-applied iodine. J Dent Res, v. 58, n. 4, p. 1317-1326, Apr. 1979.

5. EMILSON, C. G.; AXELSSON, P.; KALLENBERG, L. Effect of mechanical and chemical plaque control measures on oral microflora in schoolchildren. Community Dent Oral Epidemiol, v. 10, n. 3, p. 111-116, 1982.

6. GARCIA-GODOY, F.; MEDLOCK, J. W. An SEM study of the effects of air-polishing on fissure surfaces. Quintessence Int, v. 19 , n. 7 , p. 465-467, July 1988.

7. HÖFLING, J. F.; CURY, J. A.; MOREIRA, B. W.; PETERS, F. C.; USBERTI, A. C. Índices de estreptococos e lactobacilos em escolares de Piracicaba. Estudo longitudinal. Rev Bras Odont, v. 48, n. 3, p. 43-48, maio/jun. 1991.

8. HOSOYA, Y.; JOHNSTON, J. W. Evaluation of various 
LANZA, C. R. M; LIMA, J. E. de O.; TORRES, S. A.; MACHADO, M. A. de A. M. Effect of professional dental prophylaxis with sodium bicarbonate jet on the cariogenic microbiota. Pesq Odont Bras, v. 14, n. 1, p. 87-92, jan./mar. 2000.

cleaning and polishing methods on primary enamel. $\mathbf{J}$ Pedodont, v. 13, n. 3, p. 253-269, Spring 1989.

9. KLOCK, B.; KRASSE, B. Effect of caries-preventive measures in children with high numbers of $S$. mutans and lactobacilli. Scand J Dent Res, v. 86, n. 4, p. 221-230, July 1978.

10. KOGA, C. Y.; UNTERKIRCHER, C. S.; FANTINATO, V.; SHIMIZU, M. T.; JORGE, A. O. C. Testes de atividade de cárie. Avaliação de diferentes métodos. RGO(Porto Alegre), v. 43, n. 3, p. 141-144, maio/jun. 1995.

11. KÖHLER, B.; PETTERSSON, B. M.; BRATTHALL, D. Streptococcus mutans in plaque and saliva and development of caries. Scand J Dent Res, v. 89, n. 1, p. 19-25, Jan./Feb. 1981.

12. LIMA, J. E. de O. Um plano de prevenção para consultório odontopediátrico. RGO(Porto Alegre), v. 40, n. 6, p. 395-399, nov./dez. 1992.

13. LIMA, S. N. M. de; VERRI, R. A. Efeitos da aplicação de bicarbonato de sódio sob pressão no tratamento básico periodontal e na remoção da placa bacteriana. Rev Paul Odontol, v. 6, n. 1, p. 2-10, jan./fev. 1984.

14. LINDQUIST, B.; EMILSON, C. G.; WENNERHOLM, K. Relationship between mutans streptococci in saliva and their colonization of the tooth surfaces. Oral Microbiol Immunol, v. 4, n. 2, p. 71-76, June 1989.

15. MARTA, S. N. Avaliação do efeito do jato de bicarbonato de sódio no esmalte de dentes permanentes jovens. Bauru,1997. 81p. Dissertação (Mestrado) - Faculdade de Odontologia de Bauru, Universidade de São Paulo.

16. NUTI-SOBRINHO, A.; LIMA, S. N. M. de; WATANABE, I. Estudo da ação do Profident sobre a placa bacteriana dental através da microscopia eletrônica de varredura. Rev Paul Odontol, v. 6, n. 1, p. 34-59, jan./fev. 1984.

17. SCHAEKEN, M. J. M.; CREUGERS, T. J.; VAN DER HOEVEN, J. S. Relationship between dental plaque indices and bacteria in dental plaque and those in saliva. J Dent Res, v. 66, n. 9, p. 1499-1502, Sept. 1987.

18. SCHAEKEN, M. J. M.; JONG, M. H.; FRANKEN, H. C. M.; VAN DER HOEVEN, J. S. Effects of highly concentrated stannous fluoride and chlorexidine regimens on human dental plaque flora. J Dent Res, v. 65, n. 2, p. 57-61, Jan. 1986.

19. SVANBERG, M.; LOESCHE, W. J. The salivary concentration of Streptococci mutans and Streptococci sanguis and their colonization of artificial tooth fissures in man. Arch Oral Biol, v. 22, p. 441-447, 1977.

20. TOGELIUS, J.; KRISTOFFERSSON, K.; ANDERSON, H.; BRATTHALL, D. Streptococcus mutans in saliva: intraindividual variations and relation to the number of colonized sites. Acta Odontol Scand, v. 42, n. 3, p. 157-163, 1984.

21. VAN DER HOEVEN, J. S.; ROGERS, A. H. Factors affecting the stability of the resident dental plaque microflora of specific pathogen-free rats in relation to the ability to resist colonization by Streptococcus mutans. Arch Oral Biol, v. 24, p. 787-800, 1979.

22. WEINBERGER, S. J.; WRIGHT, G. Z. Variables influencing Streptococcus mutans testing. Pediatr Dent, v. 12, n. 5, p. 312-315, Sept./Oct. 1990.

23. WIKNER, S. Short term effect of mechanical plaque control on salivary concentration of S.mutans and lactobacilli. Scand J Dent Res, v. 94, n. 4, p. 320-326, 1986.
Recebido para publicação em 24/02/99 Enviado para reformulação em 22/06/99 Aceito para publicação em 13/12/99 